\title{
Analiza kulturoznawcza dwóch akapitów z Pamiętników Jana Chryzostoma Paska
}

DOI: 10.19195/2083-7763.7.10

W niniejszym artykule kultura ujmowana będzie jako sposób bycia podług wartości. Definicję tę zaproponował Stanisław Pietraszko, twórca wrocławskiego kulturoznawstwa. Żywił on przekonanie, że kulturoznawstwo może być samodzielną i autonomiczną dziedziną badawczą oraz że autonomia ta zasadza się na istotowym związku kultury z wartościami. Twierdził ponadto, iż inne ujęcia, nawet jeśli są owocne poznawczo, czynią z kulturoznawstwa subdyscyplinę innych nauk, na przykład socjologii, historii czy literaturoznawstwa. Tutaj zostawimy jednak problem całościowego ujęcia teorii kultury Pietraszki oraz szczegółowych rozstrzygnięć dotyczących wartości, potrzeb, kultury i cywilizacji. Odnosimy się jedynie do głównych postulatów teoretycznych uczonego.

Definiując kulturę jako sposób bycia podług wartości, nie możemy też nawiązać do utrwalonej praktyki badawczej, gdyż badanie sposobów bycia podług wartości jest obecnie postulatem. Dlatego też niezbędne jest dookreślenie aksjotycznego rozumienia kultury. Ujmowanie kultury tak, jak to proponujemy, nie powinno zatem wiązać się z całkowitym pomijaniem pewnych typów wartości czy też odmawianiem części z nich tego statusu. Stanisław Pietraszko namysł nad kulturą połączył z zadaniem poszukiwania wartości kulturowo doniosłych, lecz w taki sposób, aby odrzucać i abstrahować od wszystkich pozostałych. Kluczowe w jego teorii było odróżnienie wartości i potrzeb. Takie przedsięwzięcie nie mogło zakończyć się pozytywnie i dodatkowo wiązało się z brakiem operacjonalizacji jego koncepcji, a badania empiryczne w zasadzie były niemożliwe. Łatwiej byłoby w tym ujęciu mówić o tym, co kulturą nie jest, niż o tym, co nią 
jest ${ }^{1}$. Na przykład autor źródła, które będzie analizowane w artykule, w swoich pamiętnikach pisze o piciu alkoholu. Raz pije, aby zapomnieć o pozostawionej w Danii ukochanej, raz dla zdrowia, innym razem - bo taka moda polska. Bywa też, że pije z ciekawości smaku nieznanych wcześniej trunków. I wreszcie - dla dobrej zabawy. Ten akt o dużej wadze kulturotwórczej wiąże się więc z realizacją wielu różnych typów wartości. Wykluczenie z horyzontu zainteresowań przyjemności czy witalności poważnie zaburzy aksjotyczną strukturę Paskowego świata przeżywanego, którego niebłahą częścią jest alkohol. Potrzeby i wartości są z sobą nierozerwalnie związane, a czasami nieodróżnialne.

Najpierw należy wyodrębnić typy wartości, a następnie pytać o ich hierarchię wyrażoną w danym źródle. W tym miejscu nie do przecenienia są ustalenia poczynione na gruncie aksjologii przez Maxa Schelera. Dokonane przezeń wyróżnienie i dokładna charakterystyka typów wartości daje badaczowi kultury znakomite narzędzie ${ }^{2}$. Dlatego pytamy o to, w jaką hierarchię układają się wartości religijne, poznawcze, prawne (społeczne), estetyczne, witalne, utylitarne i hedonistyczne. Właściwym adresatem tego pytania są źródła w najszerszym sensie. Źródło to wszystko, na podstawie czego możemy sformułować sąd o przeszłości, przy czym pierwszorzędnym dla nas źródłem są oczywiście źródła narracyjne. Każdy tekst traktujemy wówczas jako ekspresję, świadectwo, odzwierciedlenie danego świata wartości, a zadanie historyka kultury polega na rekonstrukcji właściwej określonemu światu przeżywanemu hierarchii wartości, wcześniej uchwyconych, rozpoznanych, odczytanych. Dodajmy, że aprioryczna hierarchia wartości, przedstawiona przez Schelera, nie musi być zachowana w konkretnych realizacjach. Historyk kultury nie jest jednak moralistą i zadanie badawcze nie polega na tropieniu błędów w życiu moralnym jednostek czy grup społecznych. Celem jest bowiem rekonstrukcja swoistej dla danej jednostki hierarchii wartości, nawet jeśli wartości obiektywnie niższe stawiane są ponad wyższymi. Dlatego typy wartości traktujemy jako elementy, które mogą być dowolnie układane, także sprzecznie ze światem wartości badacza czy z obiektywnym porządkiem wartości ${ }^{3}$.

Takie ambicje poznawcze mają pewne skutki badawcze. Szczególnie uprzywilejowana jest $\mathrm{w}$ takich badaniach perspektywa mikrohistoryczna, a studia nad każdym źródłem są czasochłonne, gdyż wymagają umiaru, ostrożności i aptekarskiej precyzji w formułowaniu sądów. Bardzo trudno uzyskać sądy ogólne, a w punkcie wyjścia wszelkie przedsądy i stereotypy należy odrzucić. Źródło jest wówczas tylko pewną kulturową możliwością. Od razu nie wiemy przecież,

${ }^{1}$ Mówiąc o teorii Pietraszki, mam na myśli tylko i wyłącznie opublikowane teksty. Socjolog J. Żurko, uczeń S. Pietraszki, jest w trakcie opracowywania wieluset stron wykładów nagrywanych w latach osiemdziesiątych. Zbiory te mogą rzucić inne światło na spuściznę twórcy kulturoznawstwa.

2 M. Scheler, Der Formalismus in der Ethic und die materiale Wertethic, Francke-Verlag-Bern 1954, s. 125-131.

3 Pisząc o obiektywnej hierarchii wartości, nawiązujemy do ustaleń Maxa Schelera i do pisanej przez niego hierarchii wartości. Zob. przypis 2. 
na ile jest reprezentatywne dla szerszych grup społecznych - ale też taka generalizacja nie jest celem badań. Wiemy przecież doskonale, jak niewielki jest korpus źródeł, które mamy do dyspozycji, i jak przygodne są to często zbiory. Zdajemy sobie także sprawę, że lwia część tekstów dotyczy elity i faktycznie niewielkiej części społeczeństwa. Jednakże podkreślmy ponownie, że naszą ambicją poznawczą jest uchwycenie pewnego możliwego sposobu bycia podług wartości. Oczywiście dzięki poszerzaniu grupy badanych tekstów formułowane twierdzenia zyskują moc, do określenia zakresu społecznej obowiązywalności potrzeba jednak narzędzi, którymi historia kultury nie dysponuje. Poprzestaje ona na uzyskaniu wglądu na podstawie źródeł, którymi dysponujemy, w te swoiste światy możliwe kultury.

Złudne jest również przekonanie o niepoznawalności świata wartości jako świata najgłębiej subiektywnego, czyli odnoszącego się do podmiotu, do osoby, jej uczuć, motywów, intencji. Zakłada się wówczas, że między osobą a aktami, które spełnia, jest - mówiąc metaforycznie - przepaść, i w związku z tym teksty, nad którymi pracujemy, w lwiej części są nieme. Dokumenty, które badamy, to wówczas jedynie „façon de parler”, a nie znaczące świadectwo dostrzeganych i preferowanych dawniej wartości. Znakomity historyk angielski Peter Burke $\mathrm{z}$ jednej strony twierdzi, że najważniejszym aspektem kultury jest świat wartości jej uczestników, $\mathrm{z}$ drugiej zaś odpowiedzi na takie pytania uznaje za najbardziej spekulatywne i najmniej uzasadnione w badaniach historycznych. Twierdzi, że wartości nie są wyrażone w tekstach (źródłach) ${ }^{4}$. Teksty to dla niego konwencjonalne formy, a nie zbiory sądów, ocen, wartościowań. Badacza kultury w takim paradygmacie obowiązuje nieufność wobec źródeł, ponieważ źródła nie są dla niego świadectwem faktycznych wartościowań, lecz wyrazem konwencji. Tworzą więc swoistą fasadę, którą albo należy zburzyć, albo pogodzić się z powierzchownością naszych sądów. Ta krytyczna postawa przyjmuje jednak bardzo daleko idące twierdzenia dotyczące zarówno statusu źródła, jak i tekstu, a także człowieka, a że przy okazji wygłasza często nieświadomie apoteozę własnej kultury, żywiąc przekonanie, że istnieje tylko jedna hierarchia wartości i jeden porządek motywów działania, to już zupełnie inna sprawa.

W związku z powyższymi ustaleniami analizę fragmentu źródła, która jest właściwą treścią artykułu, opieramy na następujących twierdzeniach:

1. Kultura to sposób bycia podług wartości. Tak ujmowana kultura jest częścią świata przeżywanego.

2. Wartości to takie aspekty przedmiotu, które motywują do skierowanych ku niemu aktów i działań.

3. Warunkiem właściwego rozpoznania wartości przedmiotu jest uchwycenie całej hierarchii wartości.

4. Źródła to kulturowe mikrokosmosy reprezentujące dane światy wartości.

${ }^{4}$ P. Burke, Kultura ludowa we wczesnonowożytnej Europie, przeł. R. Pucek, M. Szczubiałka, Warszawa 2009. 
5. Analiza źródeł pozwala uchwycić możliwy w danym czasie i miejscu sposób wartościowania.

Po owej szczęśliwej wiktoryjej, zrobiwszy tę robotę prawie we trzech godzinach, zaraz tam osadził na tej fortecy Wojewoda kapitana Wąsowicza z ludźmi. Poszliśmy nazad, kożdy do swego stanowiska, bo trzeba było w tak wielką uroczystość mszej świętej słuchać. Mieliśmy księdza, ale nie było aparatu. Jeno cośmy w lassy weszli, aż ks. Piekarskiemu wiozą aparat, po który był nocą wyprawił. Tak tedy stanęło wojsko; nagotowano do mszej na pniaku ściętego dębu i tam odprawiło się nabożeństwo, napaliwszy ogień do rozgrzewania kielicha, bo mróz był tęgi. Te Deum laudamus śpiewano, aż po lessie rozlegało. Klęknąłem księdzu Piekarskiemu służyć do mszej; ujuszony, ubieram księdza, aż Wojewoda rzecze: „Panie bracie, przynajmniej ręce umyć”. Odpowie ksiądz: „Nie wadzi to nic, nie brzydzi się Bóg krwią rozlaną [dla] imienia Swego". A potem naszych luźnych ${ }^{207}$ spotykaliśmy, wiezących nam suplement ${ }^{208}$ różny. Gdzie kto swego zastał, tam siadł i jadł z owego wczorajszego głodu. Wojewoda wesoło jechał, że to prawie niezwyczajnym przykładem, bez armaty i piechot, wziął fortecę taką; to utrumque $^{209}$ mógłby był mieć od kurfistrza blisko stojącego, ale fantazyja w nim była, że nie chciał się kłaniać, ale żeby do niego samego ta regulowała się sława. Ufając w Bogu, porwał się i dokazał 5 .

Najwyraźniej widoczne powyżej są wartości religijne. Organizują one cały fragment i im poświęca sarmacki pamiętnikarz najwięcej miejsca, choć to nie od nich zaczyna się wybrany przez nas cytat. Czytamy bowiem o szczęśliwym zwycięstwie, o fortecy i o wojsku, a więc o tym, co związane z wartościami witalnymi. Na dalszym planie, $w$ tych pierwszych zdaniach można dostrzec także wartości prawne (społeczne). Mówi się o tytułach (wojewoda, kapitan), a przede wszystkim o organizacji wojska i swoistym rytmie kampanii wojennej. Podkreśla ją także pedanteria, $\mathrm{z}$ jaką Pasek odnotowuje, że cała robota zajęła prawie trzy godziny. To też uznać można za sznyt organizacyjny. Zwycięskie wojsko, dobrze dowodzone przez Czarnieckiego, zajmuje sprawnie fortece i wybrane stanowiska. Spodziewalibyśmy się dalszego opisu żołnierskiego życia, a jednak okazuje się, że cała ta żołnierska krzątanina ma zupełnie inny cel. Nie o witalność idzie i nie o zachowanie porządku dla niego samego. Celem jest bowiem przygotowanie mszy. Msza jest przy tym wpisana oczywiście w porządek społeczny, Pasek powiada przecież, że „trzeba było mszej słuchać”, a jednak jest to wydarzenie przede wszystkim religijne.

Wojsko po zwycięskiej bitwie zajmuje się z największą pieczołowitością przygotowaniem nabożeństwa. Ma przy tym, co w świecie Paska oczywiste, swojego kapelana, jezuitę ks. Piekarskiego. Problemem jednak jest brak naczyń i szat liturgicznych niezbędnych do przeprowadzenia mszy (autor mówi o nich ogólnie, wymieniając jedynie kielich mszalny) i wokół nich zrazu zawiązuje się intryga. Mimo to zapobiegliwość wojskowego kapelana pozwala na przeprowadzenie „tak wielkiej uroczystości”.

Drugi wątek wskazujący na wagę wartości religijnych dotyczy Paskowego służenia do mszy. Rycerz jest brudny i zakrwawiony. Spotyka się to z wyraźną

5 J.Ch. Pasek, Pamiętniki, oprac. R. Pollak, Warszawa 1989, s. 18. 
krytyką ze strony Czarnieckiego, który beszta Paska: „Panie bracie, przynajmniej ręce umyć”, co z kolei prowokuje księdza Piekarskiego do interwencji — „Nie wadzi to nic, nie brzydzi się Bóg krwią rozlaną [dla] imienia Swego".

Mamy zatem do czynienia z konfliktem dotyczącym charakteru wartości religijnych. Czarniecki domaga się od swojego żołnierza należytego okazywania szacunku rytuałom religijnym, a co za tym idzie - Bogu - przez właściwy wygląd i czystość. Tymczasem jezuita zapewnia, że w Paskowym brudzie nie ma niczego niestosownego. Twierdzi, że częścią ofiary jest też krew nieprzyjaciół na rękach i, jak możemy przypuszczać, ubraniu rycerza. Możemy więc powiedzieć, że w świetle tego fragmentu Bóg Sarmatów jest Panem surowym, brutalnym i krwawym, i w świecie Paska jest to zupełnie normalne. Ofiara z krwi, poświęcenie rycerskie, udział w słusznej wojnie, w wojnie sprawiedliwej, jest czymś właściwym i pożądanym. I w istocie wymiar religijny prowadzonych wojen jest zresztą obecny w całym pamiętniku jako najważniejsza i najwyższa wartość. $\mathrm{W}$ ten sposób sarmacki pamiętnikarz „zarabia na duszne zbawienie”. Podkreślmy też to, że w sporze Czarnieckiego z Piekarskim Bóg ujmowany jest personalnie. Czegoś chce, czegoś oczekuje, nagradza i karze. Jest przy tym aktywnym uczestnikiem wszystkich wydarzeń. Przygląda się mszy oraz cieszy gorliwością zakrwawionego rycerza.

$\mathrm{W}$ rozmowie Czarnieckiego z ks. Piekarskim można dostrzec relację między kilkoma typami wartości. Najpierw uwidaczniają się prawne i w jakimś sensie estetyczne, albowiem Pasek, zdaniem wojewody, zachowuje się niewłaściwie, łamie dobry obyczaj (porządek prawny), po drugie brudne ubranie i ręce nie licują ze służeniem do mszy. Zwróćmy uwagę, że reakcja Czarnieckiego świadczy o randze wartości religijnych. Msza organizuje porządek prawny, witalny i estetyczny zarówno w wymiarze zbiorowym (krzątające się wojsko), jak i indywidualnym (Pasek służący do mszy). Tymczasem interwencja księdza Piekarskiego związana jest z uznaniem i wywyższeniem ofiary żołnierskiej. Świadectwo poświęcenia jest ważniejsze niż to, co estetyczne, niż to, co z dobrym obyczajem związane. Składanie ofiary ma oprócz religijnego sens witalny, dlatego po wartościach religijnych umieścić należy witalne. Tę szczególnie istotną w pamiętnikach Paskowych relację między religijnością i witalnością oraz szczególnie wysokie miejsce wartości witalnych dostrzec można również $w$ ostatnich zdaniach omawianego fragmentu. Widzimy więc „wesołego wojewodę" Czarnieckiego, a źródłem jego radości jest zwycięstwo, które był odniósł bez „stosownego sprzętu”. Nie sposób bowiem zdobywać fortece bez artylerii i piechoty, a jemu się udało. Mógł wojewoda czekać na pomoc duńskich sojuszników, tymczasem żądza sławy pchnęła sarmackich rycerzy do walki. Jest to konstrukcja homerycka, w której rywalizuje się o wieniec chwały bez względu na koszta i konsekwencje. Najwidoczniej nie jest to niezgodne z regułami sarmackiej sztuki wojennej. Przeciwnie - ryzyko podjęte przez Czarnieckiego jest słuszne. Nie chciał dzielić się sławą i nie chciał prosić o pomoc, nie chciał się korzyć, i jest to uznane przez pamiętnikarza za właściwe. Oto wyraz 
sarmackiej fantazji. Odwaga, dzielność i rzeczona fantazja nie wystarczają jednak i Pasek podsumowuje opowieść o zadowoleniu dowódcy wskazaniem na właściwą przyczynę sukcesu oraz zwycięstwa. Czarniecki wygrał, bo „ufał w Bogu”. To zaufanie pozwoliło „porwać się i dokazać” własnej dzielności. Religijność i witalność to dwie kluczowe w Paskowym świecie wartości.

W tym ostatnim fragmencie mowa była także o wartościach utylitarnych. Wyraźnie i bezwzględnie ustępują one miejsca religijnym i witalnym, ale nie możemy powiedzieć, że są nieistotne. Zostały wszak dostrzeżone i odnotowane przez pamiętnikarza, a więc podejmując się rekonstrukcji sposobu bycia podług wartości, musimy je odnotować. Zarówno Pasek, jak i wojewoda wiedzą, czego potrzeba do skutecznego oblężenia, wiedzą też, jak je zorganizować, skąd może nadejść pomoc i jak ją zdobyć. Odrzucenie tego jest aktem wyboru, jest klarownym przedłożeniem sławy i witalności nad swoistą pragmatykę wojenną. Niemniej jest ona także obecna. Wartości utylitarne pojawiają się zresztą od samego początku. Zorganizowanie wojska, przeprowadzenie uroczystej mszy w cokolwiek niesprzyjających okolicznościach, zapobiegliwość księdza Piekarskiego i wreszcie sprawne zaprowiantowanie wygłodzonej przecież armii świadczą o niebłahych kompetencjach $\mathrm{w}$ tej dziedzinie oraz o wadze wartości utylitarnych. Zarazem jednak Sarmaci wybierają wojnę i modlitwę zamiast zysku i interesu nie dlatego, że nie potrafią zatroszczyć się o wartości utylitarne, lecz dlatego, że podporządkowują je innym wartościom. Przedstawiciele współczesnej pamiętnikowi angielskiej gentry, z Samuelem Pepysem ${ }^{6}$ na czele, dokonują innego wyboru, niżej stawiając sławę, zbawienie, bohaterstwo lub po prostu nie dysponując stosowną fantazją. Różnica między Pamiętnikami Paska a Dziennikami Samuela Pepysa jest uderzająca, choć są to przecież niemal rówieśnicy, z podobnej grupy społecznej, żyją zaś w zupełnie odmiennych światach wartości ${ }^{7}$. Wracając jednak do analizy fragmentu Pamiętników Paska, odnotujmy jeszcze jeden aspekt wartości witalnych: jedzenie. Po bitwie i po mszy żołnierze byli głodni, gdy więc dostarczono im prowiant, gdzie go kto odebrał, tam jadł. Niemało jest w źródle takich fragmentów. Znajdziemy opisy wielodniowych biesiad, ale warto pamiętać, że mają one silny kontrapunkt w opisach głodu i swoistej żołnierskiej ascezy. Opisy jedzenia mają u Paska związek $\mathrm{z}$ wartościami hedonistycznymi i poznawczymi. Autor rejestruje rozmaite smaki, wymienia potrawy, zapisuje, co gdzie i jak się jada. W tym fragmencie jedzenie ma jednak wymiar tylko witalny (głód) oraz utylitarny (organizacja prowiantu), nie zaś hedonistyczny. Wrażliwości sensualnej, a tym samym wartościom hedonistycznym, pamiętnikarz daje wyraz przy opisie mszy. Oczywiście jest to wyraz przede wszystkim Paskowego talentu literackiego,

6 S. Pepys, Dzienniki, wyb. i przeł. M. Dąbrowska, Warszawa 1966.

7 Szczegółowe porównanie obydwu źródeł wykracza poza ramy i cele niniejszego artykułu. W tym miejscu chcemy tylko wskazać na nieoczywistość Paskowego świata wartości i że nie można domniemywać mechanicznych związków między poszczególnymi typami wartości. Pepys i Pasek są sobie kulturowo obcy, i jest to obcość bardzo daleko idąca. 
niemniej ujmujące są detale, na które zwraca uwagę. Msza zorganizowana w lesie, po zwycięskiej bitwie jest niezwykle zmysłowa. Pasek widzi i przedstawia detale - pniak ściętego dębu, kielich, zakrwawione ręce, szaty liturgiczne. Oprócz zmysłu wzroku angażuje także dotyk. Rejestruje mróz i ogień, opowiada o ogrzewaniu kielicha mszalnego i po raz kolejny, w jeszcze innym kontekście, podkreślmy ręce pobrudzone zaschniętą krwią. I wreszcie, na koniec, to niezwykłe zdanie: Te Deum laudamus śpiewano, aż po lesie rozlegało". Pasek uważnie przygląda się światu, ale też z ujmującą uwagą i starannością go dotyka oraz słucha, ponieważ wartości hedonistyczne zajmują ważne miejsce w jego hierarchii wartości.

Porównajmy teraz omówiony akapit z innym fragmentem Pamiętników:

Wjeżdżając tedy Czarniecki do Lachowic w dzień Najświętszej Panny, wyszli przeciwko niemu processionaliter zakonnicy, szlachta, szlachcianki i kto tylko był w owym ciężkim oblężeniu, „witaj!” wołając, „zawitaj, niezwyciężony wodzu, niezwyciężony wojenniku, zawitaj od Boga nam zesłany obrońco!” Byli i tacy, osobliwie z białych głów,co wołali: „Zbawicielu nasz!” Zatulał uszy czapką, nie chcąc owego słuchać podchlebstwa. Kiedy zaś po nim wjeżdżał Sapieha, połowy tego aplauzu nie było, tylko proste przywitanie, choć to jego własne domicilium. Zsiadał[o] tedy do kościoła rycerstwa siła i z naszego, i z litewskiego wojska. Dopieroż Te Deum laudamus, dopiero tryumf! Z armat bito, aże ziemia drżała; a potem nabożeństwo śliczne, kazania, gratulacyje, dzięki Bogu za dobrodziejstwa i wszędy pełno radości, pomieszanej z płaczem; bo tam wszyscy magnatowie z księstwa litewskiego do tej fortece posprowadzali się byli. Wesoła to wiktoryja bardzo wszystkim z tej racyjej, że to po owych nieszczęśliwościach pierwsze ojczyźnie przyniosła szczęście, gdyż już Moskwa tak byli wzięli górę, że gdziekolwiek się o wojsku naszym dowiedzieli, już tak na nich szli, jak po pewne zwycięstwo, gotowe już mając dybki i kajdany na więźniów, co się znajdowało i w obozie pod Lachowicami; aleć się na nich samych przygodziły, bo ich w nie kazano kować. Nasprowadzał tedy Sapieha armaty zdobycznej siła do Lachowic, onej ślicznej, spiżowej wszystko; i jednego działa nie obaczył żelaznego. Czarniecki posłał ich do Tykocina 20 i kilka, przyłączywszy do swojej dawnej dwie zdobyczne, srodze długie i nośne. Kiedy otrąbiono, żeby więźniów oddawać,okrutnie się Czarnieckiego bali i płakali. Ja swego oddałem zaraz, idąc do Mińska po komisarzów; ale insi, których nie zaraz oddano, płakali, prosili, żeby ich nie oddawać ${ }^{8}$.

Już w pierwszym zdaniu mamy do czynienia ze splotem trzech typów wartości: religijnych, witalnych i społecznych. Zacznijmy od religijnych. W świecie Paska czas mierzony jest porządkiem liturgicznym. Czarniecki wjeżdża do Lachowic w dzień Najświętszej Panny, a zgromadzony i wdzięczny tłum uznaje go za obrońcę przez Boga zesłanego. To bardzo ważne, że ta dziękczynna litania na samym końcu zmienia adresata z Czarnieckiego na Boga. Pasek odnotowuje bluźniercze porównania Wojewody do Zbawiciela, łagodzi je jednak na dwa sposoby: po pierwsze, „osobliwie wołanie tako pochodziło od białogłów”, po drugie - zyskał tym okazję, by pochwalić Czarnieckiego za pokorę. „Zatulał uszy czapką, nie chcąc owego słuchać podchlebstwa”. Właściwie cały akapit jest takim przechodzeniem od wartości religijnych do witalnych i z powrotem. Całe życie zorganizowane jest podług tych dwóch wartości. Triumfujący wódz, bałwochwalczo

8 J.Ch. Pasek, op. cit., s. 66. 
porównywany do Boga, pierwsze kroki kieruje do kościoła. Słychać wiwaty i radość oswobodzonego tłumu. Wojewoda zmierza jednak na mszę, jak po każdej bitwie albo szerzej - po każdym wydarzeniu. Witalność spleciona jest bardzo mocno z religijnością. Zwraca uwagę ponownie personalne wyobrażenie Boga, i tak jak w poprzednim akapicie wyraźne jest przekonanie Paska o tym, że Bóg jest zaangażowany w bieg spraw tego świata, że decyduje o zwycięstwie i porażce. Nawet zgromadzony tłum, nazywając Czarnieckiego zbawicielem, dziękuje za to, że Bóg go zesłał. Możliwości ludzkie są więc niewielkie, akcent zawsze pada na wszechmoc Bożą.

W akapicie tym Pasek chwali oddział, do którego należy, za waleczność, za powodzenie, za zwycięstwo. Możemy domniemywać, że jest dumny ze wspólnoty, do której przynależy. Jednocześnie wiele miejsca poświęca oddziałom dowodzonym przez Sapiehę. Przy czym bardziej sugeruje niż mówi wprost o wyższości Czarniecczyków, głos oddając raczej tłumowi litewskiemu niż sobie i swoim towarzyszom. Wystarczy to, aby pokazać zalety Czarnieckiego, które są jasno i wyraźnie oddane przez pamiętnikarza. „Kiedy zaś po nim wjeżdżał Sapieha, połowy tego aplauzu nie było, tylko proste przywitanie, choć to jego własne [...]”.

W kontekście wartości prawnych rodzi się wątpliwość dotycząca stosunku do kobiet. Niestosowne, choć zrozumiałe dla Paska wiwaty na cześć Czarnieckiego wznosi cały zgromadzony w Lachowicach tłum, ale miarę przekraczają białogłowy. „Byli i tacy, osobliwie z białych głów, co wołali: „Zbawicielu nasz!« Zatulał uszy czapką, nie chcąc owego słuchać podchlebstwa". Czy byłby to wyraz lekceważenia, poczucia wyższości wobec kobiet? Pamiętniki nie dają podstaw do takiego twierdzenia, niemniej w analizowanym akapicie niewłaściwe zachowanie tłumaczone jest właśnie płcią.

Witalność pojawia się w już w pierwszym zdaniu. Uwidacznia się nie tylko w pochwałach zwycięzcy, wojownika, nie tylko gdy mowa o triumfach wojennych, lecz jej świadectwem jest także euforyczność opisu. Wiwatujący tłum, strzelanie z armat, radość, „wesoła wiktoryja” - to także dowody, dość oczywistej w tej sytuacji, witalności. Wiążemy z nią nie tylko radość zwycięzców, ale także strach pokonanych. „Kiedy otrąbiono, żeby więźniów oddawać, okrutnie się Czarnieckiego bali i płakali". Pamiętnikarz jest przekonany, że słusznie i dobrze jest, gdy dowódca wzbudza strach przeciwników, i to nie tylko na polu bitwy, lecz także poza nim. Pamiętnikarz wydaje się dumny z powodu lęku, który wzbudza Wojewoda, a przerażeni jeńcy wzbudzają wesołość, a nie współczucie. Natomiast dwojako można interpretować zdanie o regularnych klęskach, które „wojsko nasze” ponosiło wcześniej. U Paska pojawiają się bowiem dwa sposoby mówienia o porażkach. Albo zaznacza, że dotyczy to kogo innego niż Czarniecczycy, albo - i sądzę, że tak jest w tym przypadku - uznaje klęski i porażki za element normalnego żołnierskiego doświadczenia. Nie jest tak, że Polacy zawsze wygrywają. Co więcej - zwykle klęski interpretowane są jako dopust Boży, jako kara za grzechy. Jest jednak w tym akapicie inna ciekawa myśl. Czytamy: 
Już Moskwa tak byli wzięli górę, że gdziekolwiek się o wojsku naszym dowiedzieli, już tak na nich szli, jak po pewne zwycięstwo, gotowe już mając dybki i kajdany na więźniów, co się znajdowało i w obozie pod Lachowicami; aleć się na nich samych przygodziły, bo ich w nie kazano kować.

Pewny siebie Sarmata, opokę znajdujący w Bogu i własnej szabli znajduje upodobanie w podkreślaniu niestabilności świata. Oto Rosjanie przyzwyczaili się do zwycięstw nad polskim i litewskim wojskiem, a tymczasem los niespodziewanie się odmienił. W zdaniu tym Pasek nie mówi ani o męstwie Czarnieckiego, ani o Bogu, tak jak miało to miejsce w innych fragmentach. Konstatuje po prostu odmianę losu. Ot, Rosjanie przygotowali dyby i kajdany, gdyż przyzwyczaili się do łatwych zwycięstw, a tymczasem sami zostali w nie zakuci. Może to być konstatacja faktów i zbiegu okoliczności, drwina z nazbyt pysznego wroga albo ważna część obrazu świata. Twierdzimy jednak, że zdanie to ma głęboki sens moralny i wyraża Paskowy stosunek do świata. Omawiany fragment pozwala tylko na sformułowanie takiej hipotezy, lecz w świetle całego Paskowego pamiętnika przekonanie o kole fortuny i jego niespodziewanych obrotach jest bardzo silne. Niestałość świata jest dla sarmackiego pamiętnikarza oczywista.

$\mathrm{Na}$ koniec podkreślmy charakterystyczną dla niego wrażliwość zmysłową. Ponownie przedstawia nam bogatą fonosferę i ponownie bacznie przygląda się otoczeniu. Pisze o „ślicznych armatach, o ślicznej mszy, słucha krzyków, zawołań i bicia z armat". Zmysłowa aktywność współwystępuje z przekonaniem o niestałości świata. Być może to skrupulatne przyglądanie się rzeczom i sytuacjom ma swoje źródło w obrazie świata jako miejsca nieprzyjaznego, niestałego, a często wrogiego. Według Paska głupim jest ten, co pokłada w „światowości” jakiekolwiek nadzieje.

Powyższa próba analizy zaledwie dwóch akapitów Pamiętników Jana Chryzostoma Paska ma być tylko przykładem perspektywy kulturoznawczej, czyli takiej, która w centrum swojego zainteresowania stawia wartości. Ujęcie kultury jako sposobu bycia podług wartości nie jest ani dominujące, ani popularne w dziedzinie nazywanej kulturoznawstwem. Jednakże argumenty przedstawione przez wrocławskich uczonych ${ }^{9}$ nie uległy dezaktualizacji i jeśli warto podejmować trud konstytuowania kulturoznawstwa jako samodzielnej dyscypliny, to musi wiązać się to $\mathrm{z}$ badaniem aksjosfery.

\section{Bibliografia}

Bednarek S., Pojmowanie kultury i jej historii we wspótczesnych syntezach dziejów kultury polskiej, Wrocław 1995.

Burke P., Kultura ludowa we wczesnonowożytnej Europie, przeł. R. Pucek, M. Szczubiałka, Warszawa 2009.

9 W związku z badaniami historyczno-kulturalnymi szczególnie istotna jest książka S. Bednarka, Pojmowanie kultury i jej historii we współczesnych syntezach dziejów kultury polskiej, Wrocław 1995. 
Galarowicz J., Fenomenologiczna etyka wartości, t. I, Kraków 1997.

Pasek J.Ch., Pamiętniki, oprac. R. Pollak, Warszawa 1989.

Pepys S., Dzienniki, wyb. i przeł. M. Dąbrowska, Warszawa 1966.

Pietraszko S., Kultura: studia teoretyczne i metodologiczne, Wrocław 2012.

Pietraszko S., [Wykłady i seminaria ze zbiorów J. Żurki] — maszynopis w posiadaniu autora.

Scheler M., Der Formalismus in der Ethic und die materiale Wertethic, Francke-Verlag-Bern 1954.

Tischner J., Myślenie według wartości, Kraków 1993.

Węgrzecki A., Scheler, Warszawa 1975.

\section{Cultural analysis of two paragraphs of Jan Chryzostom Pasek's Memoirs}

\section{Summary}

The article was written as an outcome of the workshops organized during conference "Personal accounts in research experience". Its aim was to present the differences between sociology, history, literary studies and history of culture. The aim of the author was to present a research method specific to cultural studies. Culture was understood, according to S. Pietraszko, as a way of living towards the values and as such it is a part of the Lebenswelt, whereas the typology of values was taken from the writings of Max Scheler. The analysis of historical sources is aimed at grasping a possible valuation in a given time and space. In two paragraphs of "Memoirs" by Jan Chryzostom Pasek particular types of values were found and a question about their precedence was asked. Dominant values in the Pasek's Lebenswelt were holiness and vitality. They were above (in the hierarchy of values) law, beauty and utility. The analysis enabled reconstruction of piety of Sarmatian memoirist, his image of God and his views about war, violence and community. 